\title{
HUBUNGAN KEMAMPUAN AWAL DAN KEPERCAYAAN DIRI \\ DENGAN PRESTASI BELAJAR MATEMATIKA PADA \\ SISWA KELAS V SDN 4 RENSING \\ TAHUN PEMBELAJARAN 2016/2017
}

\section{Yuliana Susanti \\ STIT Palapa Nusantara Lombok-NTB \\ Email: yuliana.susanti27@ gmail.com}

\begin{abstract}
The purpose of this study is 1) Want to know the relationship of the initial ability of students in improving the achievement of learning Mathematics in grade V SDN 4 Rensing. 2) Want to know the relationship of students' self confidence in improving Mathematics learning achievement in grade V SDN 4 Rensing students. 3) Want to know the relationship of initial ability with confidence in the students of grade V SDN 4 Rensing. 4) Want to know the relationship of initial ability and confidence to the achievement of learning Mathematics in grade V SDN 4 Rensing year of learning 2016/2017. This research uses facto expo research. This study concludes that: 1) Initial ability correlates significantly with mathematics learning achievement. 2) Confidence is significantly related to mathematics learning achievement 3) Initial ability to relate significantly with confidence 4) The interaction of initial ability and confidence relationship is significantly related to mathematics learning achievement with contribution of $69.1 \%$.
\end{abstract}

Kata Kunci: Kemampan awal, Kepercayaan Diri, Prestasi Belajar

\section{PENDAHULUAN}

Pembelajaran Matematika di SD merupakan salah satu kajian yang selalu menarik untuk dikemukakan karena adanya perbedaan karaktristik khususnya antara hakekat anak dengan hakekat Matematika. Pada anak usia SD sedang mengalami perkembangan dalam tingkat berpikirnya. Ini karena tahap berpikir mereka masih belum formal, malahan para siswa SD dikelas-kelas rendah bukan tidak mungkin sebagian dari mereka berpikirnya masih berada pada tahapan pra konkrit dilain pihak Matematika adalah ilmu deduktif, aksiomatik, formal, hirarkis, abstrak, bahasa simbol yang padat arti dan semacamnya. ${ }^{1}$

Pada pembelajaran Matematika di SD, sesuatu yang abstrak dapat saja dipandang sederhana menurut kita yang sudah formal namun dapat saja menjadi sesuatu yang sulit dimengerti oleh anak yang belum formal oleh karena itulah tugas guru di sekolah ialah menolong anak mengembangkan kemampuan intlektualnya sesuai dengan perkembangan intlektual anak. Setiap individu anak akan berdeda dalam hal minat, bakat, kemampuan keperibadian, dan pengalaman lingkungannya dan keanekaragaman intelegensinya, maka

1 Karso, Pendidikan Matematika 1 (Jakarta: Pusat Penerbitan Universitas Terbuka: 2000).hal.14 
faktor-faktor ini harus diperhatikan agar proses pembelajaran matematika di SD dapat berhasil.

Proses interaksi belajar-mengajar adalah inti dari kegiatan pendidikan. Sebagai inti dari kegiatan pendidikan, proses intraksi belajar-mengajar adalah suatu upaya untuk mencapai tujuan pendidikan. Tujuan pendidikan itu tidak akan tercapai apabila proses interaksi belajar mengajar tidak pernah berlangsung dalam pendidikan. Guru dan siswa adalah dua unsur yang terlibat langsung dalam proses itu. Oleh karena itu diperlukan peranan guru dalam menciptakan intraksi belajar-mengajar yang kondusif.

Pendidikan di Indonesia sudah tentu tidak bisa lepas dari tujuan pendidikan, yang dilakukan untuk kepentingan bangsa dan rakyat Indonesia. Tujuan pendidikan bangsa Indonesia tertera dalam Undang-Undang RI Nomor 2003 sebagai berikut; mengembangkan kemampuan dan membentuk watak serta peradaban bangsa yang bermartabat dalam rangka mencerdaskan kehidupan bangsa, bertujuan untuk berkembangnya potensi peserta didik agar menjadi manusia yang beriman dan bertakwa kepada Tuhan YME, berakhlak mulia, sehat, berilmu, cakap kreatif, mandiri dan menjadi warga negara yang demokratis serta bertanggung jawab. ${ }^{2}$

Sesuai dengan kekhususan yang ada pada masing-masing bahan materi pelajaran, baik sifat maupun tujuan yang berlainan antara satu mata pelajaran dengan mata pelajaran yang lainnya yang disebabkan karena tujuan yang berbeda, perbedaan latar belakang individual anak, perbedaan situasi dan kondisi, perbedaan pribadi dan kemampuan pendidik, dan adanya sarana dan prasarana (fasilitas) yang berbeda di lingkungan sekolah. Maka khususnya dalam bidang studi matematika guru tidak hanya dituntut untuk meningkatkan prestasi belajar siswa melalui tugas-tugas ektrakurikuler saja, namun lebih dari itu guru dituntut untuk mampu memahami perbedaan karakteristik siswa baik kecerdasan intelektual maupun kecerdasan emosional mereka, serta memberikan motivasi dalam meningkatkan kepercayaan diri siswa untuk proses peningkatan prestasi belajar mereka.

Salah satu faktor utama yang mempengaruhi efisiensi belajar siswa adalah kepercayan diri, dengan adanya kepercayaan diri pada siswa, setiap siswa akan berusaha untuk mewujudkan keinginannya agar dapat berhasil. Untuk kelancaran belajar perlu adanya rasa optimis, percaya diri akan kemampuan diri sendiri dan yakin dapat menyelesaikan tugastugas dengan baik, dan siswa harus yakin bahwa apa yang dipelajarinya berguna bagi dirinya kelak dikemudian hari.

Untuk mewujudkan dan mensukseskan tujuan pendidikan, guru harus mampu memberikan bimbingan yang mudah untuk dipahami dan dipraktikkan oleh siswa agar dapat meningkatkan prestasi belajar mereka. Prestasi bermakna hasil dari suatu kegiatan yang telah dikerjakan, diciptakan, baik secara individual maupun kelompok. Sedangkan belajar adalah suatu aktifitas yang sadar akan tujuan, yang bertujuan mengadakan perubahan dalam diri individu. Sebagaimana dikatkan Sardiman A.M. bahwa belajar adalah serangkaian kegiatan

\footnotetext{
${ }^{2}$ Made Pidarta , Managamen Pendidikan Indonesia, (Jakarta:Rineka Cipta: 2004).
}

Hal.6. 
jiwa-raga, psikofisik menuju perkembangan pribadi manusia seutuhnya, yang menyangkut unsur cipta, rasa dan karsa, ranah kognitif, afektif dan psikomotorik". 3

Prestasi belajar siswa pada bidang studi Matematika dipengaruhi oleh kemampuan awal (IQ) kecerdasan Intlektual, sebab dengan adanya kemaampuan berpikir siswa yang cepat dan memiliki daya ingatan yang kuat anak akan mampu berpikir kritis dan berpikir kreatif sehingga memberi peluang untuk mengangkat persoalan yang sifatnya multi dimensional, dapat mengantisipasi kemungkinan jawaban yang jamak (jawaban lebih dari satu).

Potensi yang dimiliki anak memungkinkan dapat memfungsikan keseluruhan kerja otak, yang mencakup kecerdasan intelektual dan kecerdasan emosional sehingga prestasi belajar yang diharapkan akan merupakan hasil dari kerja otak. Binet menyatakan sifat hakekat intelegensi itu ada 3 macam yaitu: 1) kecenderungan untuk menetapkan dan mempertahankan tujuan tertentu. 2) kemampuan untuk mengadakan penyesuaian dengan maksud untuk mencapai tujuan itu. 3) kemampuan untuk mengkritik diri sendiri, kemampuan untuk belajar dari kesalahan yang telah dibuatnya. ${ }^{4}$ Berdasarkan pendapat ahli diatas kemampuan intelegensi untuk belajar dari kesalahan yang telah dibuat berperan dalam memicu minat siswa SD untuk mempelajari mata pelajaran Matematika.

Sehubungan dengan hal di atas, proses belajar mengajar peserta didik merupakan komponen input dalam sistem pendidikan yang selanjutnya diperoses dalam pendidikan sehingga menjadi manusia yang berkualitas. Dalam hal ini peserta didik adalah subjek belajar artinya peserta didik merupakan tolak ukur keberhasilan proses belajar mengajar. Kesemuanya itu tidak terlepas dari metode, teknik, dan pendekatan yang harus digunakan guru (pendidik) khususnya pada mata pelajaran matematika.

\section{METODOLOGI PENELITIAN}

Metode penelitian menyangkut alat dan teknik untuk melaksanakan penelitian. Hal ini dapat dilihat dari pemilihan metode yang tepat untuk meneliti suatu masalah atau obyek penelitian di eksperimenkan dan mengkaji suatu obyek secara sengaja. Adanya perbedaan keadaan obyek penelitian dilapangan, memungkinkan untuk menggunakan metode atau memilih metode yang berbeda pula. Sehubungan dengan hal ini Sugiyono (1999) mengemukakan bahwa: "Penelitian ex post facto adalah suatu penelitian yang dilakukan untuk meneliti pristiwa yang telah terjadi dan kemudian melihat kebelakang untuk mengetahui faktor-faktor yang dapat menimbulkan kejadian tersebut. ${ }^{5}$

Karena dalam penelitian ini keadaan obyek penelitian sudah ada secara wajar artinya peneliti tidak perlu lagi memperlakukan lagi subyek penelitian untuk menimbulkan gejala yang diinginkan. Maka metode yang digunakan dalam penelitian ini adalah ex post facto. Penggunaan metode ini dimaksudkan untuk hubungan kemampuan awal dan kepercayaan diri

3 Djamarah, Prestasi Belajar dan Kompetensi Guru. (Surabaya: Usaha Nasional: 1991). Hal.21

${ }^{4}$ Suryabrata Sumadi, Metodologi Penelitian. (Jakarta: Rajawali:1991).hal.133

5 Riduwan, Belajar Mudah Penelitian Untuk Guru-Karyawan dan Peneliti Pemula. (Bandung. Alfabeta: 2004.).hal.50 
dengan prestasi belajar Matematika pada siswa kelas V SDN 4 Rensing kecamatan Sakra Barat tahun pembelajaran 2016/2017.

Untuk mengumpulkan data, maka setiap variabel perlu diidentifikasi. Terdapat 2 (dua) macam variabel dalam penelitian ini, yakni: (a). Variabel Bebas (Independent Variable) Adalah kondisi-kondisi atau karakteristik-karakteristik yang oleh peneliti dimanipulasi dalam rangka untuk menerangkan hubungannya dengan fenomena yang diobservasi. Variabel ini disebut juga dengan variabel pengaruh karena mempengaruhi variabel lain. Disini yang menjadi variabel bebasnya adalah kemampuan awal dan kepercayaan diri. (b) Variabel Terikat (Dependent Variable) Yaitu kondisi atau karakteristik yang berubah atau muncul ketika penelitian mengintroduksi, pengubah atau mengganti variabel bebas disebut juga variabel terpengaruh. Yang menjadi variabel terikatnya adalah prestasi belajar Matematika siswa kelas V SDN 4 Rensing.

Setelah data terkumpul dari hasil pengumpulan data perlu segera digarap atau diolah data tersebut. Dalam buku-buku lain sering disebut data preparation, adapula data analisis". ${ }^{6}$ seorang ahli berpendapat bahwa "teknik analisis data adalah mengelompokkan data berdasarkan variabel dan jenis responden, mentabulasi data berdasarkan variabel dari seluruh responden, menyajikan data tiap variabel yang diteliti, melakukan perhitungan untuk menjawab rumusan masalah dan untuk menguji hipotesis. ${ }^{7}$

Dari kedua pendapat di atas maka untuk memperoleh gambaran yang jelas mengenai data dari masing-masing variabel serta untuk menguji hipotesis penelitian terlebih dahulu dilakukan analisis data yaitu Teknik Uji Persyaratan Analisis, Uji Normalitas Data, Uji linieritas data, Teknik Uji Hipotesis

\section{HASIL PENELITIAN DAN PEMBAHASAN}

Hasil deskriptif data responden variabel yaitu kemampuan awal $\left(x_{1}\right)$, kepercayaan diri $\left(x_{2}\right)$, dan prestasi belajar Matematika (y), diuraikan sebagai berikut: Pertama, Kemampuan awal $\left(x_{1}\right)$ terdapat jumlah kasus 17 orang yang menyelesaikan soal uraian, diperoleh hasil untuk rata-rata (mean) sebesar 5,76; titik tengah (median) $=2,0$; nilai yang sering muncul (mode) 5,0; simpangan baku (standar deviasi) $=1,44$; tingkat penyebaran data (varians) $=$ 2,066 ; rentangan $($ rnge $)=5$; skor minimal dari data $=4,0$ dan skor maksimal dari data $=$ 9,sedangkan jumlah skor keseluruhan adalah sebesar 98.

Kedua, Kepercayaan diri $\left(x_{2}\right)$ terdapat jumlah kasus 17 orang yang diobservasi, diperoleh hasil untuk rata-rata (mean) sebesar 2,59; titik tengah (median) $=5,0$; nilai yang sering muncul (mode) 2, simpangan baku (standar deviasi) $=1,12$; tingkat penyebaran data (varians) $=2,257$; rentangan (range) $=3$; skor minimal dari data $=1$ dan skor maksimal dari data $=4$,sedangkan jumlah skor keseluruhan adalah sebesar 44. Ketiga, Prestasi belajar Matematika (y) terdapat jumlah kasus 17 orang yang mengerjakan soal uraian, diperoleh hasil untuk rata-rata (mean) sebesar 7,06; titik tengah (median) $=7$, nilai yang sering muncul

6 Arikunto Arikunto. Dasar Dasar Evaluasi Pendidikan. Edisi Revisi. (Jakarta. Bumi Aksara: 2006).hal.2009

${ }^{7}$ Sugiyono, Metode Penelitian Pendidikan Pendekatan kualitatif, Kuantitatif dan $R$ $\& D$. (Bandung. Alfabeta: 2006).hal.2007 
(mode $)=7 ; \quad$ simpangan baku (standar deviasi) $=1,48$, tingkat penyebaran data (varians) $=$ 2,183; rentangan (range) $=5$; skor minimal dari data $=4$ dan skor maksimal dari data $=$ 9,sedangkan jumlah skor keseluruhan adalah sebesar 120 .

Komposisi data responden antar variabel $x_{1}, x_{2}$, dan y seperti tabel berikut:

\section{Tabel 1}

Data responden antar variabel $x_{1}$, dan $x_{2}$, dengan $\mathbf{y}$

\begin{tabular}{|l|l|l|l|l|l|l|l|l|l|l|}
\hline Variabel & Kasus & Mean & Median & Mode & $\begin{array}{l}\text { Standar } \\
\text { Deviasi }\end{array}$ & Varians & Range & Min & Max & Jumlah \\
\hline X1 & 17 & 5,76 & 5 & 5 & 1,44 & 2,066 & 5 & 4 & 9 & 98 \\
\hline X2 & 17 & 2,59 & 2 & 2 & 1,12 & 1,257 & 3 & 1 & 4 & 44 \\
\hline Y & 17 & 7,06 & 7 & 7 & 1,48 & 2,183 & 5 & 4 & 9 & 120 \\
\hline
\end{tabular}

Hasil analisis korelasi dan regresi ganda untuk $x_{1}$, dan $x_{2}$, dengan y

Tabel 2

Hasil analisis korelasi $x_{1}$, dan $x_{2}$, terhadap $\mathbf{y}$

\begin{tabular}{|l|l|l|l|}
\hline & $\mathrm{X} 1$ & $\mathrm{X} 2$ & $\mathrm{Y}$ \\
\hline $\mathrm{X} 1$ & 1 & 0,789 & 0,507 \\
\hline $\mathrm{X} 2$ & 0,789 & 1 & 0,656 \\
\hline $\mathrm{y}$ & 0,507 & 0,656 & 1 \\
\hline
\end{tabular}

Dari dua tabel diatas dapt disimpulkan bahwa dat yang diperoleh dari hasil penelitian yang dilakukan berpola linier karena dat berpola linier apabila $\mathrm{F}$ hitung $<\mathrm{F}$ tabel.

Tabel 3

Hasil analisis korelasi ganda $x_{1}$, dan $x_{2}$, terhadap $\mathbf{y}$

\begin{tabular}{|l|l|l|l|}
\hline Nilai korelasi & Korelasi ganda & Nilai $\mathrm{F}$ \\
\hline $\mathrm{r} x_{1 .} y=0,507$ & \multirow{3}{*}{0,656} & $f_{\text {htung }}=5,278$ & $f_{\text {tabel }}=3,74$ \\
\cline { 1 - 1 } $\mathrm{r} x_{2 .} y=0,656$ & & $\begin{array}{l}F_{\text {htung }}>F_{\text {Tabel }} \text { atau 5,278 }>3,74 \\
\text { Berarti signifikan }\end{array}$ \\
\cline { 1 - 1 } $\begin{array}{l}\mathrm{r} \\
x_{1 .} x_{2}=0,789\end{array}$ & & \\
\hline
\end{tabular}

Tabel 4

Hasil analisis regresi $x_{1}$, dan $x_{2}$, dengan y

\begin{tabular}{|l|l|l|l|l|}
\hline Jumlah & Koefisien & $R x_{1} x_{2}$ & Nilai $\mathrm{F}$ \\
\cline { 1 - 1 }$\sum x_{1 .} y=17,236$ & $b_{1}=0,521$ & \multirow{2}{*}{0,657} & $f_{\text {htung }}=5,319$ & $f_{\text {Tabel }}=3,74$ \\
\cline { 1 - 4 }$\sum \sum x_{2 .} y=17,412$ & $b_{2}=0,865$ & & $\begin{array}{l}F_{\text {htung }}>F_{\text {Tabel }} \text { atau 5,319 }>3,74 \\
\text { Berarti signifikan }\end{array}$ \\
\hline
\end{tabular}




\section{Uji Persyaratan Analisis}

\section{Uji Normlitas Data}

Pembuktian normalitas data dimaksudkan untuk menguji apakah skor dalam ubahan yang diteliti telah menghampiri distribusi normal atau tidak. Normalitas data yang diuji dalam penelitian ini adalah kemampuan awal $\left(x_{1}\right)$ dengan prestasi belajar Matematika (y), dan kepercayaan diri $\left(x_{2}\right)$ dengan prestasi belajar matematika (y) pada siswa kelas V SDN 4 Rensing.

\section{Tabel 5}

Uji Normalitas Data

\begin{tabular}{|l|l|l|l|}
\hline Ubahan & $X_{\text {Hitung }}^{2}$ & $X_{\text {Tabel }}^{2}$ & Keputusan \\
\hline$x_{1}$ terhadap $Y$ & 2,718 & 11,070 & Normal \\
\hline$x_{2}$ terhadap $Y$ & 1,580 & 11,070 & Normal \\
\hline
\end{tabular}

Dari tabel diatas dapat disimpulkan bahwa ubahan-ubahan dari data berdistribusi normal.

\section{Uji Linieritas}

Untuk menguji apakah data hasil penelitian berpola linier atau tidak, peneliti menggunakan tekhnik anava.

\section{Tabel 6}

Ringkasan anava varibel $x_{1}$, dan y untuk uji linieritas

\begin{tabular}{|c|c|c|c|c|c|}
\hline $\begin{array}{l}\text { Sumber } \\
\text { Variansi } \\
\text { (VS) }\end{array}$ & $\begin{array}{l}\text { Drajad } \\
\text { kebebasn } \\
(\mathrm{DK})\end{array}$ & $\begin{array}{l}\text { Jumlah } \\
\text { Kuadrat } \\
(\mathrm{JK})\end{array}$ & $\begin{array}{l}\text { Rata-rat Jumlah } \\
\text { Kuadrat(RJK) }\end{array}$ & $F_{\text {Hitung }}$ & $F_{\text {Tabel }}$ \\
\hline Total & 17 & 882 & - & $-0,453$ & 3,36 \\
\hline $\begin{array}{l}\text { Regresi } \\
\text { (n) }\end{array}$ & 1 & 847,059 & 847,059 & \multirow{5}{*}{\multicolumn{2}{|c|}{$\begin{array}{l}\text { Ternyata } F_{\text {htung }}<F_{\text {Tabel }} \\
\text { atau } 0,453<3,36 \text { maka data } \\
\text { berpola linier }\end{array}$}} \\
\hline $\begin{array}{l}\text { Regresi } \\
(\mathrm{b}-\mathrm{a})\end{array}$ & 1 & 8,979 & 8,979 & & \\
\hline Residen & 15 & 25,962 & 1,731 & & \\
\hline $\begin{array}{l}\text { Tuna } \\
\text { Cocok }\end{array}$ & 4 & $-4,979$ & $-1,245$ & & \\
\hline $\begin{array}{l}\text { kesalahan } \\
\text { (Error) }\end{array}$ & 11 & 30,216 & 2,747 & & \\
\hline
\end{tabular}

Tabel 7

Ringkasan anava varibel $x_{2}$, dan y untuk uji linieritas

\begin{tabular}{|c|c|c|c|c|c|}
\hline $\begin{array}{l}\text { Sumber } \\
\text { Variansi } \\
\text { (VS) }\end{array}$ & $\begin{array}{l}\text { Drajad } \\
\text { kebebasn } \\
\text { (DK) }\end{array}$ & $\begin{array}{l}\text { Jumlah } \\
\text { Kuadrat } \\
\text { (JK) }\end{array}$ & $\begin{array}{l}\text { Rata-rat Jumlah } \\
\text { Kuadrat(RJK) }\end{array}$ & $F_{\text {Hitung }}$ & $F_{\text {Tabel }}$ \\
\hline Total & 17 & 882 & - & $-2,625$ & 3,36 \\
\hline $\begin{array}{l}\text { Regresi } \\
\text { (n) }\end{array}$ & 1 & 847,059 & 847,059 & \multirow{2}{*}{\multicolumn{2}{|c|}{$\begin{array}{l}\text { Ternyata } F_{\text {htung }}<F_{\text {Tabel }} \\
\text { atau }-2,625<3,36 \text { maka data } \\
\text { berpola linier }\end{array}$}} \\
\hline $\begin{array}{l}\text { Regresi } \\
(b-a)\end{array}$ & 1 & 15,061 & 15,061 & & \\
\hline
\end{tabular}




\begin{tabular}{|l|l|l|l|l|}
\hline Residen & 15 & 19,88 & 1,325 & \\
\hline $\begin{array}{l}\text { Tuna } \\
\text { Cocok }\end{array}$ & 4 & $-13,48$ & $-6,74$ & \\
\cline { 1 - 3 } $\begin{array}{l}\text { kesalahan } \\
\text { (Error) }\end{array}$ & 11 & 33,567 & 2,567 & \\
\hline
\end{tabular}

\section{Interpretasi Hasil Pengujian Hipotesis}

Melakukan interpretasi hasil analisis penelitian yaitu melakukan penafsiran terhadap pengujian hipotesis walaupun hasil analisis statistik itu sendiri sudah merupakan suatu kesimpulan, tetapi belum memadai tanpa adanya interpretasi yang dikaitkan dengan rumusan masalah. Interpretasi dan pengujian diuraikan sebagi berikut: Pertama, Ada hubungan yang signifikan antara kemampuan awal dengan prestasi belajar matematika. Berdasarkan tabel 3 bahwa besarnya hubungan antara kemampuan awal $\left(x_{1}\right)$ terhadap prestasi belajar matematika (y) yang dihitung dengan koefisien korelasi adalah 0,507 atau ( $\left.\mathrm{r} x_{1} \mathrm{y}=0,507\right)$, hal ini menunjukkan hubungan yang kuat antara prestasi belajar matematika pada siswa kelas $\mathrm{V}$ SDN 4 Rensing.

Berdasarkan tabel 4. dan uji Anova tau F ternyata didapati F hitung adalah 5,187 dengan tingkat signifikan 0,05 sehingga model regresi bisa dipakai untuk memprediksi prestasi belajar matematika. Rumus regresi sebagai berikut:

$$
\begin{aligned}
\hat{y}=a+b_{1} x_{1} & =4,055+0,521 x_{1} \\
\text { Dimana }: x_{1} & =\text { Kemampun awal } \\
y & =\text { Prestasi beljar mtematika }
\end{aligned}
$$

Konstanta sebesar 4, 055 menyatakan bahwa jika tidak ada kenaikan nilai dari variabel kemampuan awal $\left(x_{1}\right)$, maka nilai prestasi belajar matematika (y) adalah 4,055. Koefisien regresi sebesar 0,521 menyatakan setiap penambahan (karena tanda + ) satu skor atau nilai kemampuan awal adalah memberikan peningkatan skor sebesar 0,521. Uji t untuk menguji signifikansi konstanta dari variabel prestasi belajar siswa, kriteria uji koefisien regresi dari variabel kemampuan awal terhadap prestasi belajar matematika sebagai berikut:

Hipotesis dalam bentuk kalimat:

Ha: Ada hubungan yang signifikan antara kemampuan awal dengan prestasi belajar siswa.

Ho: Tidak ada hubungan yang signifikan antara kemampuan awal dengan prestasi belajar siswa.

Hipotesis dalam bentuk statistik

Ha: $\left(r x_{1} y \neq 0\right)$

Ho: $\left(r x_{1} y=0\right)$.

Dasar pengambilan hipotesis yaitu dengan membandingkan nilai $t_{\text {htung }}$ dengan nilai $t_{\text {Tabel }}$ sebagai berikut:

Jika : $t_{\text {htung }}>t_{\text {Tabel }}$, maka Ho ditolak artinya koefisien regresi signifikan

$: t_{\text {hung }}<t_{\text {Tabel }}$, maka Ho diterima artinya koefisien regresi tidak signifikan 
Nilai $t_{\text {htung }}$ diambil pada lampiran 10 .

Nilai $t_{\text {htung }}$ untuk variabel $x_{1}$ terhadap $\mathrm{y}=2,114$

Nilai $t_{\text {Tabel }}$

Tingkat signifikansi $(\alpha)=0,05$

$\mathrm{Dk}=\mathrm{n}-2=17-2=15$

Uji dilakukan satu pihak sehingga nilai $t_{\text {Tabel }}=1,753$.

Keputusan

Karena $t_{\text {htung }}>t_{\text {Tabel }}$, atau $2,114>1,753$, maka Ho ditolak artinya koefisien regresi signifikan atau kemampuan awal mempunyai hubungan yang signifikan terhadap prestasi belajar matematika.

Kedua, Ada hubungan yang signifikan antara kepercayaan diri dengan prestasi belajar matematika. Berdasarkan tabel 3, bahwa besarnya hubungan antara kepercayaan diri ( $x_{2}$ ) terhadap prestasi belajar matematika (y) yang dihitung dengan koefisien korelasi adalah 0,656 atau $\left(r x_{2} y=0,656\right)$. Hal ini menunjukkan hubungan yang kuat antara kepercayaan diri dengan prestasi belajar matematika. Berdasarkan tabel 5 dari uji anova atau Ftes, ternyata didapat Fhitung adalah 11,367 dengan tingkat signifikan 0,05, sebagai model regresi dapat dipakai untuk memprediksi prestasi belajar matematika.

Dari lampiran 10 Menggambarkan bahwa persamaan regresi sebagai berikut:

$$
\begin{gathered}
y=a+b_{2} x_{2}=4,82+0,865 x_{2} \\
\text { Dimana: } \quad x_{2}=\text { Kepercayaan diri } \\
y=\text { Prestasi belajar matematika }
\end{gathered}
$$

Konstanta sebesar 4, 82 menyatakan bahwa jika tidak ada kenaikan nilai dari variabel kepercayan diri $\left(x_{2}\right)$, maka nilai prestasi belajar matematika (y) adalah 4,82. koefisien regresi sebesar 0,865 menyatakan setiap penambahan (karena tanda + ) satu skor atau nilai kepercayaan diri akan memberikan peningkatan skor sebesar 0,865 . Uji t untuk menguji signifikansi konstanta dari variabel prestasi belajar siswa, kriteria uji koefisien regresi dari variabel kepercayaan diri terhadap prestasi belajar matematika sebagai berikut:

Hipotesis dalam bentuk kalimat:

Ha: Ada hubungan yang signifikan antara kepercayaan diri dengan prestasi belajar siswa.

Ho: Tidak ada hubungan yang signifikan antara kepercayaan diri dengan prestasi belajar siswa.

Hipotesis dalam bentuk statistik

Ha: $\left(r x_{2 .} y \neq 0\right)$

Ho: $\left(r x_{2 .} y=0\right)$.

Dasar pengambilan hipotesis yaitu dengan membandingkan nilai $t_{\text {htung }}$ dengan nilai $t_{\text {Tabel }}$, sebagai berikut:

Jika : $t_{\text {htung }}>t_{\text {Tabel }}$, maka Ho ditolak artinya koefisien regresi signifikan 
$: t_{\text {htmg }}<t_{\text {Tabel }}$, maka Ho diterima artinya koefisien regresi tidak signifikan

Nilai $t_{\text {htung }}$ dimbil pada lampiran 10 Nilai $t_{\text {htung }}$ untuk variabel $x_{2}$ terhadap $\mathrm{y}=3,370$

Nilai $t_{\text {Tabel }}$

Tingkat signifikansi $(\alpha)=0,05$

$\mathrm{Dk}=\mathrm{n}-2=17-2=15$

Uji dilakukan satu pihak sehingga $t_{\text {Tabel }}=1,753$

Keputusan

Karena $t_{\text {htung }}>t_{\text {Tabel }}$, atau 3,370 $>1,753$, maka Ho ditolak artinya ada hubungan yang signifikan antara kepercayaan diri dengan prestasi belajar matematika.

Ketiga, Ada hubungan yang signifikan antara kemampuan awal dengan kepercayaan diri. Berdasarkan tabel 3 bahwa besarnya hubungan antara variabel kemmpuan awal, $\left(X_{1}\right)$ dengan kepercayaan diri $\left(X_{2}\right)$ yang dihitung dengan koefisien korelasi adalah 0,789 atau (r $\left.x_{1} \cdot x_{2}=0,789\right)$, hal ini menunjukkan hubungan yang kuat antara variabel kemampuan awal dengan variabel kepercayaan diri.

Keempat, Ada hubungan yang signifikan antara kemampuan awal dan kepercayaan diri dengan prestasi belajar matematika. Berdasarkan analisis regresi ganda terdapat $\mathrm{R}$ squere adalah 0,687 (adalah pengkuadratan dari koefisien korelasi 0,829 atau $0,829^{2}$ ) $\mathrm{R}$ squere dapat disebut koefisien determinasi yang dalam hal ini berarti 68,7 \% konstribusi variabel kemampuan awal dan kepercayaan diri terhadap prestasi belajar matematika, sedangkan sisanya 31,3 \% dapat dijelaskan oleh sebab-sebab lain. Jadi kemampuan awal dan kepercayaan diri secara simultan berhubungan terhadap prestasi belajar matematika dengan konstribusi sebesar $68,7 \%$.

Persamaan regresi ganda

$$
\hat{y}=a+b_{1} x_{1} b_{1} x_{2}=4,44+0,521+0,865 x_{2}
$$

Pada lampiran 11 Uji anova atau $\mathrm{F}$ tes, ternyata didapat $\mathrm{F}$ hitung adalah 18,54 dengan tingkat signifikansi 0,05 , maka model regresi dapat dipakai untuk memprediksi prestasi belajar siswa. Untuk menguji signifikansi kemampuan awal dan kepercayaan diri secara simultan berhubungan terhadap prestasi belajar matematika.

Kaedah pengujian signifikansi regresi berganda

$F_{\text {htung }}>F_{\text {Tabel }}$, maka signifikan

$F_{\text {htung }}<F_{\text {Tabel }}$, maka tidak signifikan

Ternyata $F_{\text {htung }}>F_{\text {Tabel }}$, tau $18,54>3,74$, maka signifikan.

\section{HASIL PENELITIAN DAN PEMBAHASAN}

Berdasarkan hasil pengujian yang telah diuraikan, maka terbukti bahwa kemampuan awal dan kepercayaan diri mempunyai hubungan yang signifikan terhadap prestasi belajar matematika pada siswa kelas V SDN 4 Rensing. Uraian selengkapnya sebagai berikut: Pertama, Kemampuan awal berhubungan secara signifikan terhadap prestasi belajar siswa. Pembahasan mengenai kemampuan awal sangat berhubungan kuat dan signifikan terhadap 
prestasi belajar siswa pada SDN 4 Rensing. Kemampuan awal pada siswa terdiri dari kemampuan kogntif (intlektual,afektif (sikap) dan psikomotorik (keterampilan). Dalam penelitian ini, peneliti hanya meneliti kemampuan kognitif saja yang merupakan salah satu unsur yang menentukan peningkatan prestasi belajar matematika pada siswa.

Penerapan dari kegiatan yang dilakukan di sekolah maupun di rumah dalam proses pembelajaran adalah penting dilakukan, sebab kemampuan sebagai ungkapan dari perwujudan diri individu termasuk kebutuhan pokok siswa yang bila terwujud memberikan rasa kepuasan dan rasa keberhasilan yang mendalam yang pada akhirnya kemampuan awal siswa dapat menentukan dan meningkatkan prestasi belajar matematika sehingga dapat disimpulkan bahwa siswa yang memiliki kemampuan awal yang tinggi dapat menentukan dan meningkatkan prestasi belajar. Berdasarkan hasil penelitian pada siswa kelas V SDN 4 Rensing, diperoleh kesimpulan bahwa cukup baiknya kemampuan awal yang dimiliki siswa akan lebih meningkatkan prestasi belajar matematika.

Kedua, Kepercayaan diri berhubungan secara signifikan terhadap prestasi belajar siswa. Pengajaran hendaknya memberi kesempatan kepada siswa untuk melakukan aktivitas berupa pekerjaan atau tugas yang harus diselesaikan atau masalah-masalah yang harus dipecahkan atas dasar kemampuan anak sendiri untuk membimbing anak kearah berdiri sendiri atas tanggung jawab sendiri, ini berarti anak akan terbina untuk percaya kepada diri sendiri, mampu mengatasi kesulitan-kesulitan dengan kemampuan sendiri, penuh inisiatif, kreatif dan berfikir kritis serta bertanggung jawab. Dengan adanya kepercayaan diri kepada siswa akan membuat siswa selalu aktif mengadakan peroses belajar dan akan membuat perhatian akan penuh, lebih tajam cara penalarannya. Disamping itu juga siswa akan lebih puas karena bukti-bukti atau dalil-dalil didapatkan sendiri, ini semua mempunyai nilai khusus, sebab anak atau siswa mendapat kepercayaan diri dalam melakukan aktifitas atau proses belajar di sekolah terutama di SDN 4 Rensing.

Ketiga, Kemampuan awal mempunyai hubungan yang signifikan dengan kepercayaan diri. Kemampuan awal merupakan faktor penting dalam menentukan dan meningkatkan prestasi belajar matematika, terutama kemampuan kognitif siswa yaitu kemampuan awal siswa dapat dilihat hasil aktifitas atau penyelesaian terhadap suatu masalah, tugas dan soal yang diberikan oleh guru kemampuan awal yang didasri kepercayaan diri dalam peroses belajar mengajar akan berdampak positif bagi peroses belajar mengajar dan perkembangan pribadi siswa. Bentuk hasil tersebut bisa terwujud melalui peningkatan atau menentukan prestasi belajar matematika pada siswa kelas V SDN 4 Rensing. Jadi dari penelitian yang dilakukan bahwa kemampuan awal dan kepercayaan diri mempunyai hubungan yang signifikan.

Keempat, Kemampuan awal dan kepercayaan diri mempunyai hubungan yang signifikan dengan prestasi belajar siswa. Kemampuan yang dimiliki siswa ada tiga yaitu kemampuan kognitif, afektif dan psikomotorik. Kemampuan yang diteliti dalam penelitian ini khususnya kemampuan kognitif (intlektual siswa) yang merupakan salah satu faktor penting dalam meningkatkan dan menentukan prestasi belajar matematika pada siswa kelas V SDN 4 Rensing. Disamping itu juga kepercayaan diri yang dimiliki siswa sangat berhubungan dengan penentuan dan peningkatan prestasi belajar matematika pada siswa kelas V SDN 4 Rensing. Dengan adanya kepercayaan diri dari siswa akan membuat siswa lebih aktif dan kreatif dalam menyelesaikan masalah matematika dan akan diselesaikan dengan penuh 
tanggung jawab serta memberikan kepuasan terhadap diri siswa atas keberhasilannya. Dengan demikian dari penelitian yang dilakukan, kemampuan awal dan kepercayaan diri berhubungan secara signifikan terhadap prestasi belajar matematika pada siswa kelas V SDN 4 Rensing Tahun Pelajaran 2016/2017.

\section{KESIMPULAN}

Besarnya hubungan antara variabel kemampuan awal $\left(x_{1}\right)$ dan kepercayaan diri $\left(x_{2}\right)$ terhadap prestasi belajar siswa (y) tergolong kuat. Sedangkan konstribusi secara bersamasama (simultan) variabel $x_{1}$, dan $x_{2}$ terhadap y adalah $R^{2} \times 100 \%$ atau $0,829^{2} \times 100 \%=68,7 \%$. Sedangkan sisanya $31,3 \%$ ditentukan oleh variabel lain. Kemudian mengenai naik turunnya prestasi belajar matematika dapat diprediksi melalui persamaan regresi; $\quad \hat{y}=a+b_{1} x_{1} b_{1} x_{2}=4,44+0,521+0,896 x_{2}$, sehingga dari hasil penelitian dapat ditarik kesimpulan sebagai berikut: (a) Kemampuan awal berhubungan secara signifikan dengan prestasi belajar matematika. (b) Kepercayaan diri berhubungan secara signifikan dengan prestasi belajar matematika. Besarnya hubungan antara variabel kemampuan awal ( $x_{1}$ ) dan kepercayaan diri $\left(x_{2}\right)$ terhadap prestasi belajar siswa (y) tergolong kuat. Sedangkan konstribusi secara bersama-sama (simultan) variabel $x_{1}$, dan $x_{2}$ terhadap y adalah $R^{2} \times 100 \%$ atau $0,829^{2} \times 100 \%=68,7 \%$. Sedangkan sisanya $31,3 \%$ ditentukan oleh variabel lain.

Kemudian mengenai naik turunnya prestasi belajar matematika dapat diprediksi melalui persamaan regresi; $\hat{y}=a+b_{1} x_{1} b_{1} x_{2}=4,44+0,521+0,896 x_{2}$, sehingga dari hasil penelitian dapat ditarik kesimpulan sebagai berikut: (a) Kemampuan awal berhubungan secara signifikan dengan prestasi belajar matematika. (b) Kepercayaan diri berhubungan secara signifikan dengan prestasi belajar matematika (c) Kemampuan awal berhubungan secara signifikan dengan kepercayaan diri. (d) Kemampuan awal dan kepercayaan diri berhubungan secara signifikan dengan prestasi belajar matematika.

\section{DAFTAR PUSTAKA}

Djamarah, 1991. Prestasi Belajar dan Kompetensi Guru. Surabaya: Usaha Nasional Made Pidarta , 2004, Managamen Pendidikan Indonesia, Jakarta:Rineka Cipta.

Mulyasa, E, 2007. Menjadi Guru Profesional Menciptakan Pembelajaran Kreatif dan Menyenangkan. Jakarta : Bumi Aksara.

Nana Sudjana. 2002. Dasar-Dasar Proses Belajar Mengajar. Bandung: Sinar Baru Algensindo

Ngalim Purwanto. 1991. Ilmu Pendidikan Teoritis dan Praktis. Bandung: PT. Remaja Rosda karya

Nurkancana Wayan, 1986. Evaluasi Hasil Belajar. Surabaya : Usaha Nasional.

Poerwadarminta, 1976. Kamus Besar Bahasa Indonesia, Jakarta: Balai Pustaka

Riduwan, 2004. Belajar Mudah Penelitian Untuk Guru-Karyawan dan Peneliti Pemula. Bandung. Alfabeta

Karso, 2000, “Pendidikan Matematika 1” Jakarta: Pusat Penerbitan Universitas Terbuka 
Sugiyono, 2006. Metode Penelitian Pendidikan Pendekatan kualitatif, Kuantitatif dan $R \& D$. Bandung: Alfabeta.

Arikunto Arikunto. 2006. Dasar Dasar Evaluasi Pendidikan. Edisi Revisi. Jakarta: Bumi Aksara

Sutrisno Hadi. 2004. "Metodologi Research", Yogyakarta: Andi

Sulistiyono, 2003, "Wawasan Pendidikan " Jakarta: Depdiknas

Suryabrata Sumadi, 1991. Metodologi Penelitian. Jakarta: Rajawali 